\title{
Morphological effects of tributyltin (TBT) in vitro on the genital system of the mesogastropoda Littorina littorea (Prosobranchia)
}

\author{
U. Deutsch \& M. Brick \\ Institut für Spezielle Zoologie und Vergleichende Embryologie, Westfälische-Wilhelms- \\ Universität Münster; Hüfferstr. 1, D-W-4400 Münster, Federal Republic of Germany
}

\begin{abstract}
This ultrastructural study investigates the pathological changes in the penial, the sperm groove and the glandular cushion epithelium in male Littorina littorea (Mesogastropoda) related to TBT (tributyltin) contamination. The results are compared with those on Ocinebrina aciculata (Neogastropoda), which shows a wide range of cell changes in the penis epithelia of male and imposex affected females. The investigation of the different penis epithelia of $L$. littorea revealed that the cells analysed show a low sensibility towards TBT. The cells display normal metabolism. Certain atypical structures like swelling microvilli and cristae which tend to lie parallel to the long axis in the mitochondria, were detected as pathological effects.
\end{abstract}

\section{INTRODUCTION}

Since the pioneer work of Smith (1971), antifouling paints containing tributyltin (TBT) are known to cause pathological changes in the genital system of snails. Particularly female individuals of populations in strongly polluted areas produce abnormal phenomena, which are termed imposex (Bryan et al., 1988) or pseudohermaphrodism (Fioroni et al., 1991). Detailed morphological and histological descriptions of imposex in different prosobranchs are given in papers by Blaber (1970), Chagot et al. (1990), Ferreira et al. (1990), Fioroni et al. (1990), Gibbs et al. (1990), and Hawkins \& Hutchinson (1990).

Usually, mesogastropods like Trivia monacha or Trivia arctica show imposex, (Stroben et al., in press), whereas Littorina littorea seems to be devoid of such TBT-related malformations in its genital system (Mattiessen et al., 1991). This result is of great importance: L. littorea dwells on nearly every European coast in rocky and sandy habitats, and therefore this species could serve as a bioindicator. Our unpublished microscopical observations on more than $3000 \mathrm{~L}$. littorea specimens from TBT-polluted sites are fully in line with the report by Mattiessen et al. (1991).

To substantiate our data we started a comprehensive investigation of the genital system in L. littorea in order to clarify cytological TBT-effects. Pathological changes were found for the first time in the penial epithelium cells of male and female Ocinebrina aciculata. This is the first detailed ultrastructural analysis of the penial epithelium, the epithelium of penial sperm groove, and the simple penial glands epithelium in Littorina littorea to be published so far, and is part of the doctoral thesis of the first author (U. Deutsch). 


\section{MATERIAL AND METHODS}

To get well substantiated statistics, we collected more than 30 adult Littorina littorea each month during the period from 1989 to 1991 in the rocky intertidal zone of Helgoland (southern North Sea, Germany), and near the biological CNRS-station at Roscoff (Bretagne, France). The intense pollution of the latter region is reflected by other prosobranchs like Nucella lapillus or Ocinebrina aciculata, which both show imposex quite commonly (Fiorino et al., 1990).

After narcotizing the animals with a $\mathrm{MgCl}_{2}$ solution ( $7 \%$ in destilled water), their shells were cracked with a vice, and sexually active males (Linke, 1933) were selected for further investigations. From these animals, tissue of the penial epithelium, the epithelium of the sperm groove, and the glandular cushion epithelium glands was dissected and fixed immediately in potassium-dichromate at a $\mathrm{pH}$ of 7.2-7.4, followed by a storage in an $\mathrm{OsO}_{4}-\mathrm{H}_{2} \mathrm{O}$ solution for 4 to 22 hours at $4{ }^{\circ} \mathrm{C}$. These specimen were rinsed with filtered sea water, dehydrated via gradated ethanol series, and finally embedded in Spurr's resin (1969). Thin sections about $1 \mu \mathrm{m}$ in thickness were cut with a Reichert Ultracut E Leica microtome and stained with $\mathrm{Pb}$-acetate for contrast. All ultrastructural analyses were performed with a Siemens Transmission Electron Microscope of the Institute for Biology (University of Münster) at $60-80 \mathrm{kV}$.

\section{RESULTS}

The penial epithelium

In Littorina littorea the penial epithelium, situated usually on the physiological left side of the penial sperm groove, has a homogeneous and more or less rectilinear basal membrane (Fig. 1). The penial epithelium consists of prismatic supporting cells which display at their apex a border of apically fixed microvilli (Fig. 2). In one sample from the Helgoland sampling site an abnormal swelling on these microvilli was observed (Fig. 3). Sense cells of the penial epithelium have apically an edge of cilia (Fig. 4) representing most probably tactile sense cells. The lateral membranes of the supporting cells are apically tightly interlinked and in rare cases desmosomes occur (Fig. 5).

The nucleus of the supporting cells, which in most cases contains a nucleolus, is oval to elongated in shape. The nucleus is situated centrally to basally and covers about one half of the cell volume; its euchromatin abundance slightly exceeds the heterochromatin. Frequently we observed an invagination of the nucleus membrane in the region of the heterochromatin. This shape indicates unequivocally that the cells are in quite an active stage (Fig. 6).

Fig. 1. The basal membrane (arrow) of the penial epithelium is homogeneous and of normal thickness; scale bar $=0.5 \mu \mathrm{m}$

Fig. 2. Microvilli of the supporting cells are fixed apically (arrow); scale bar $=0.5 \mu \mathrm{m}$. MV: microvilli

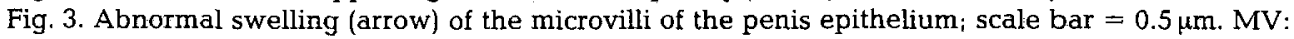
microvilli

Fig. 4. Sense cell of the penial epithelium has at its apex a border of cilia; scale bar $=1.5 \mu \mathrm{m}$. CI: cilia; MI: mitochondrium; N: nucleus 


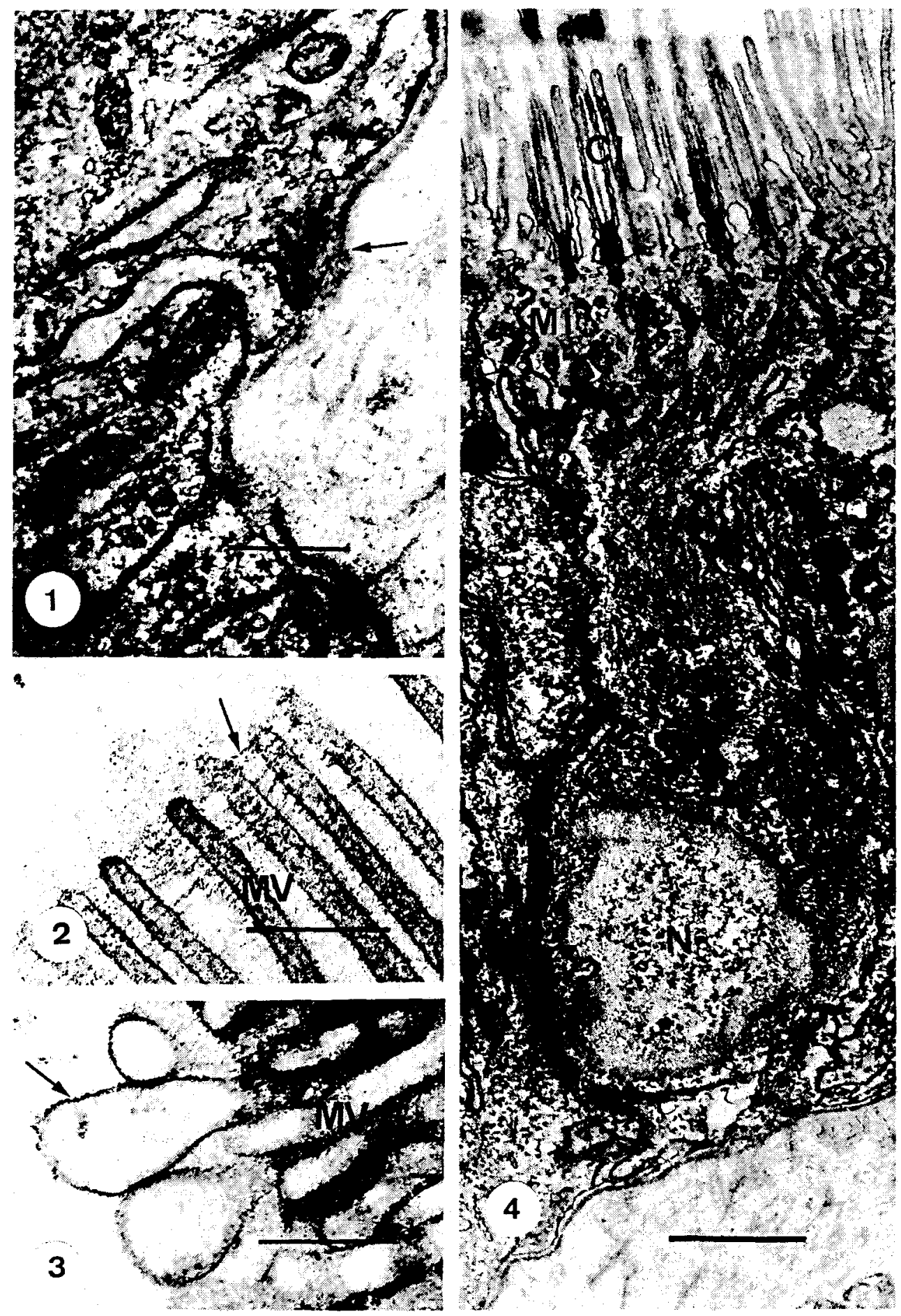


The supporting cells of the penis epithelium contain a significant number of cell organelles such as mitochondria, endoplasmatic reticulum (ER), golgi complex (GC), and pigment inclusions in varying abundances. Important cytological structures of the supporting cells are oval to elongated mitochondria with a dense grouping of cristae (Fig. 7). In a few specimen from the Roscoff sampling site, the cristae tended to lie parallel to the long axis (Fig. 8). Normally, the mitochondria are situated in the apex and around the nucleus.

Figure 9 shows that coated vesicles representing electron-permeable vacuoles are concentrated apically near pigment inclusions. In only a few cases, we observed in this region also larger vacuoles with inclusions. Smooth ER (Fig. 7) and to a lesser degree rough ER (Fig. 10) occur typically close to the nucleus. This domain is full of densely packed GC with circular vesicles (Fig. 11). Some animals, especially from the Helgoland population, display lysosomes in the apex of the supporting cells in the region that is rich with pigment inclusions (Fig. 12).

Our observations show that a normal regeneration process takes place in the penial epithelium of $L$. littorea with ejection of single cells. This process never results in exposure of the basal membrane because surrounding and succeeding cells immediately lead to a closure of the gap. The nuclei of the expelled, degenerated cells display strongly aggregated heterochromatin (Fig. 13).

\section{Glands cells of the penis epithelium}

Gland cells are concentrated in the tip of the penis. They adhere to the supporting cells by an interconnection of the cell membranes which is less pronounced than the binding between the supporting cells. Apical to the gland cells, a secretory aperture surrounded by microvilli is situated. According to their cytological characteristics, we classify the gland cells into four different types named $A, A 1, B$, and $C$ (Figs 14-17).

Gland cells of type A show membrane-linked secretion vesicles which are transparent under the electron beam (Fig. 14). On the apical side, these vesicles become homogeneous and are expelled as a whole. These gland cells contain a small, basal nucleus surrounded by mitochondria of the cristae type; differentiated cells display occasionally parts of the GC.

Compared to gland cells of type A, cells of type A1 occur more frequently in the normal penial epithelium (Fig. 15). The secretion vesicles are linked again to the membrane, but now the content of the cells display a more amorphous structure. In contrast to

Fig. 5. The lateral membrane interlinked between the supporting cells. Arrow $=$ desmosomes; scale bar $=$ to $0.5 \mu \mathrm{m}$. CM: cell membrane

Fig. 6. A supporting cell of the penial epithelium. The invagination of the nucleus membrane (arrow) appears in the region of the heterochromatin; scale bar $=2 \mu \mathrm{m}$. EU: euchromatin; HE: heterochromatin; $N$ : nucleus; $\mathrm{P}$ : pigment

Fig. 7. The supporting cells show normal oval and elongated mitochondria (arrow) with a dense grouping of cristae; scale bar $=0.5 \mu \mathrm{m}$. N: nucleus

Fig. 8. In a few species from the Roscoff sites the cristae of the mitochondria tend to lie parallel to the long axis (arrow) in supporting cells; scale bar $=0.5 \mu \mathrm{m}$. MI: mitochondria

Fig. 9. Fluid filled vesicles representing electron-permeable vacuoles in the apical cytoplasma of penis epithelium; scale bar $=1 \mu \mathrm{m}$. FV: fluid filled vesicle; $N$ : nucleus 

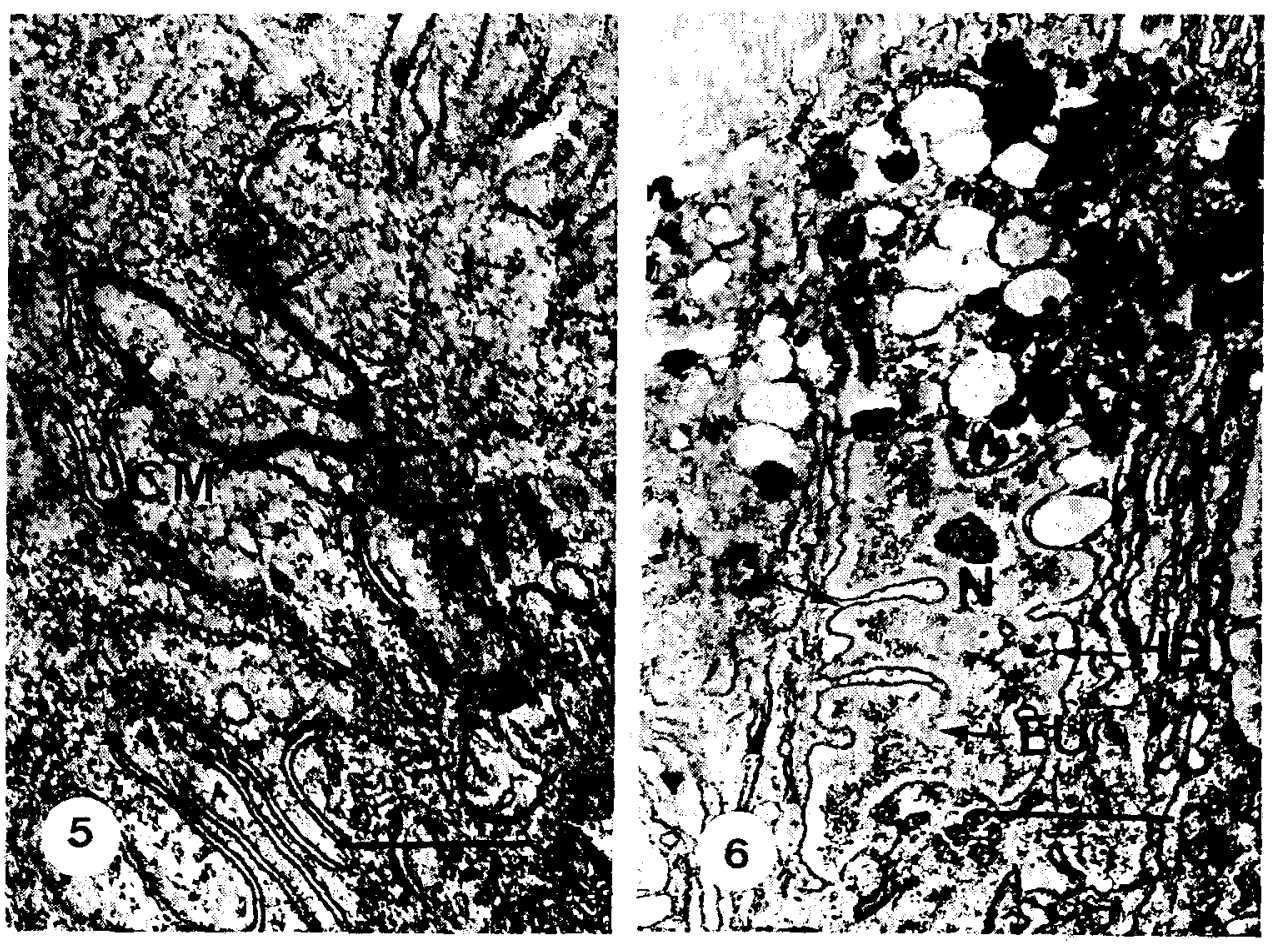

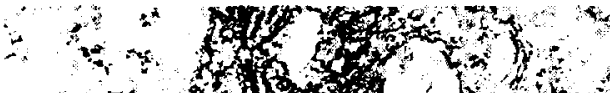

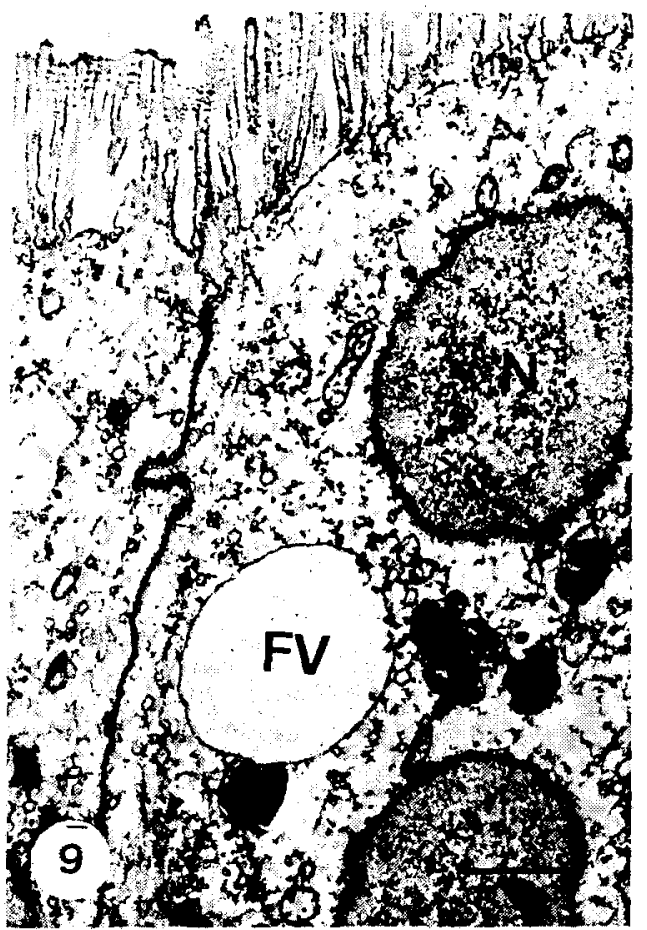


the situation in type $A$, the vesicles do not become homogeneous on the apical side but are still surrounded by a membrane during secretion. Cells of $A 1$ show basal nuclei which are enclosed by GC vesicles and mitochondria with densely packed cristae.

Gland cells of type B are highly prismatic with densely packed lipid-like secretions (Fig. 16). These secretions are not covered by a membrane, and do not become homgeneous apically during secretion. As in this case the mucus-particles are loosely packed, we could observe cell organelles like mitochondria and GC in between. Cells of type B are relatively rare; they extend from the penial tissue through the basement membrane into the penial epithelium.

Gland cells of type C differ from all the other cells in the penial epithelium in their large cell volume and in their small grana-like mucus-particles which are not always covered by a membrane. This type of cell is produced most probably in the penial tissue, and it breaks through the basal membrane, disposing its secretions on the apical side of the penial epithelium. The nucleus has a basal position in these seldom found cell types.

\section{The epithelium of the penial sperm groove}

The open penial sperm groove is situated on the physiologically left side of the penis. Its lateral supporting cells are highly prismatic whereas the more compact cells such as found in the penial epithelium support the sperm groove on the basal side. In the position apical to the supporting cells we detected an homogeneous, densely packed edge of cilia with pronounced ciliaroots (Fig. 18). The nucleus of each supporting cell is situated in a median position of the cell and covers about one third of the total cell volume. Its euchromatin abundance is slightly higher than the heterochromatin content. In its lateral part, the cell membrane is invaginated which leads to an increase in surface area.

The supporting cells contain a heterogeneous cytoplasma with a large number of different organelles. Most conspicuous is the high amount of elongated to oval, elongated mitochondria, full of densely packed cristae, in the region of the cilia-root (Fig. 19). Other organelles like mitochondria, $\mathrm{GC}$, smooth and rough ER are present near the nucleus. Snails with intense pigmentation also show pigment inclusions in the supporting cells of the penial sperm groove.

\section{Glands cells of the penial sperm groove}

Gland cells in the epithelium of the sperm groove are identical to the gland cells described above. However, type $\mathrm{A}, \mathrm{A} 1$, and $\mathrm{C}$ (Figs 14, 15, 17) are less abundant than

Fig. 10. Different cell organelles lying in the cytoplasma of supporting cells in penis epithelium; scale bar $=0.5 \mu \mathrm{m}$. GC: Golgi complex; SER: smooth endoplasmatic reticulum (ER); Arrow, rough ER

Fig. 11. Golgi body and circular Golgi vesicle (arrow) of the supporting cells; scale bar $=0.5 \mu \mathrm{m}$. GC: Golgi complex

Fig. 12. A few species from the Helgoland population display lysosomes in the apex of the supporting cells in the region rich with pigment inclusion; scale bar $=0.5 \mu \mathrm{m}$. Abbreviation: LY $=$ lysosomes

Fig. 13. A normal regeneration process in the penial epithelium of Littorina littorea with ejection of single cells. The heterochromatin is strongly aggregated; scale bar $=1.5 \mu \mathrm{m}$. BM: basal membrane; HE: heterochromatin; MV: microvilli; N: nucleus 

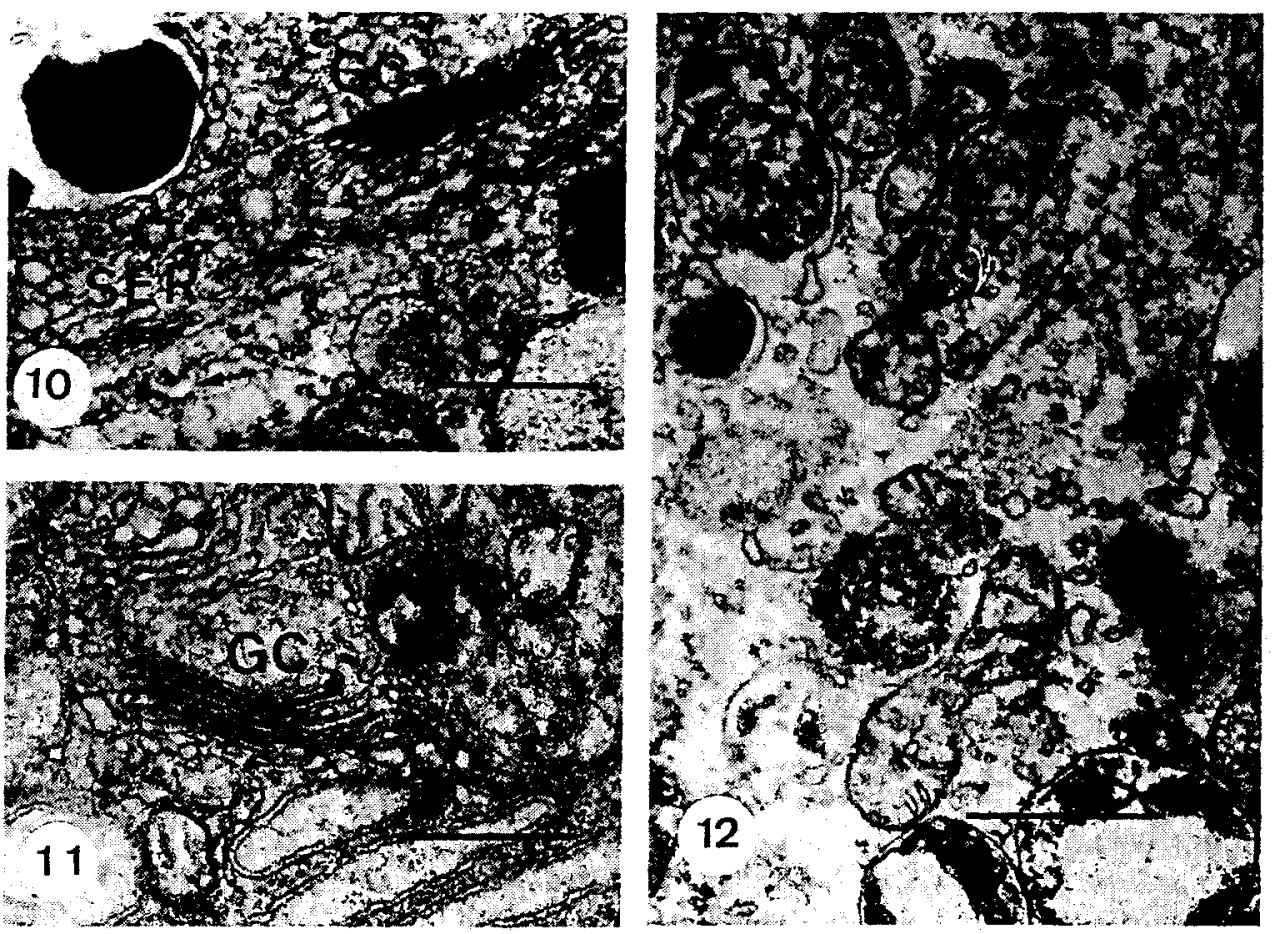

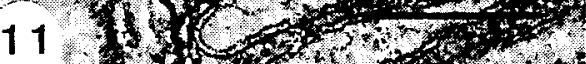

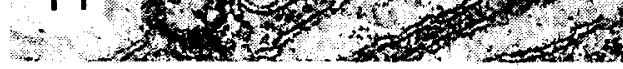

$$
\text { molas }
$$

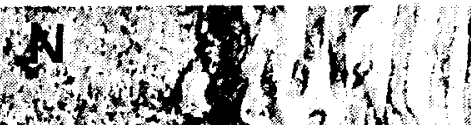

to

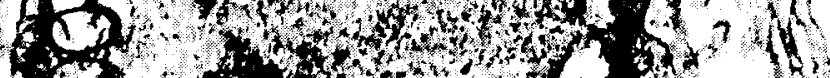

\section{MV}

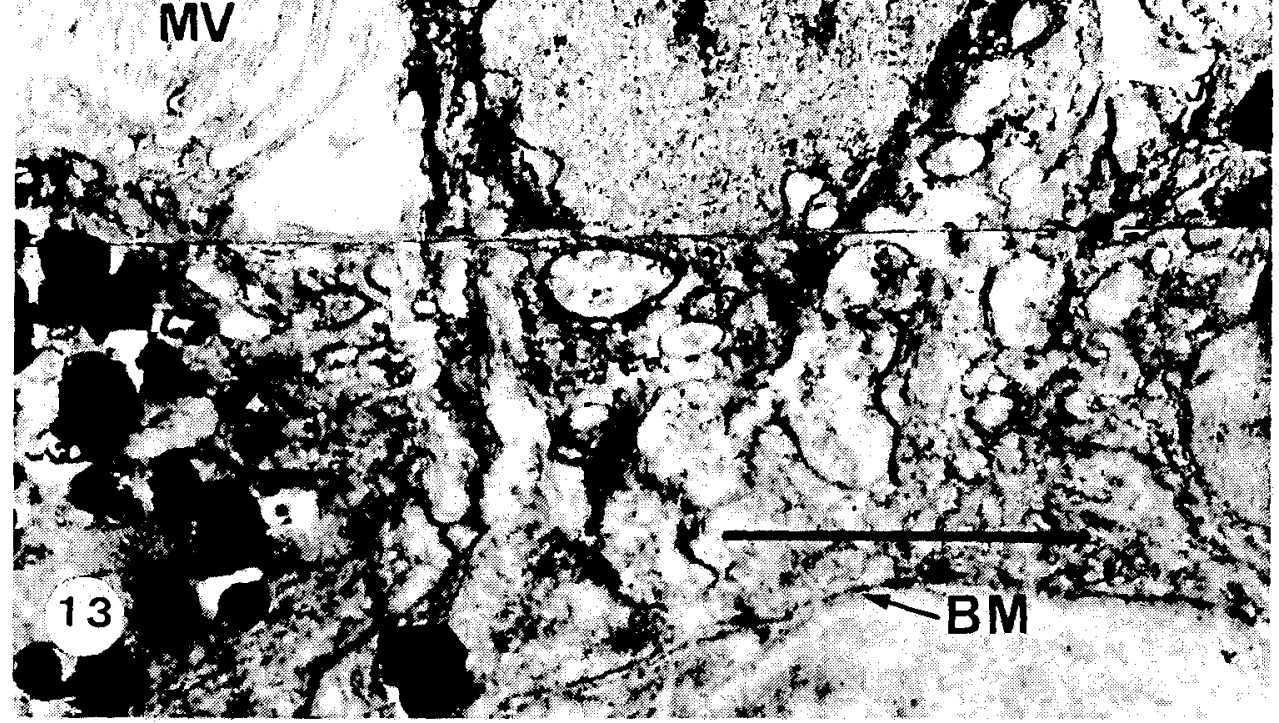


type B (Fig. 16). As described above, in the region of the sperm groove the cells of type B extend from the tissue in the epithelium (Fig. 20).

\section{Glandular cushion epithelium}

Near the tip of the penis the glandular cushion epithelium is situated on both sides, and in the region of the glandular papillae on the physiological right side of the penial sperm groove. It is characteristic of the glandular cushion epithelium that gland cells show a much higher abundance than in other epithelia. Very frequent are cells of type $C$ (Fig. 17), whereas cells of type B are absent. From a cytological point of view, the different cells in the glandular epithelium resemble those of other penial epithelia.

\section{DISCUSSION}

This electron microscopical study shows that the penial epithelium, the epithelium of the sperm groove, and the glandular cushion epithelium in Littorina littorea from strongly TBT-polluted habitats are devoid of pathological changes. In contrast, the neogastropod Ocinebrina aciculata from identical sampling sites displays conspicuous TBT-triggered anomalies in the male and especially in the female. TBT-induced penial epithelium.

The ability for resorption and secretion (cf. Moore, 1985; Herwig \& Holwerda, 1986; Lowe, 1989) of the penial epithelium seems to be more efficient in L. littorea than in $O$. aciculata: Whereas the latter snail displays a reduction of the edge of microvilli and a flattened epithelium, $L$. littorea still has a prismatic epithelium with a fully developed edge of microvilli (Figs 2,6 ). The high content of cell organelles points to an active, unreduced synthesis of the different penial epithelia. In contrast to the mitochondria of TBT-stressed $O$. aciculata which are characterized by a low number of cristae, mitochondria in L. littorea show densely packed cristae, a fact pointing to an oxidative phosphorylation on a low stress-level.

Swelling of mitochondria, as published for TBT-loaded branchiae of Salmo spec. (Chliamovitch \& Kuhn, 1977) and also found in extreme size in O. aciculata, or shrinkage of mitochondria in Anodonta spec., which is the corollary of a change in osmotic relations caused by di-n-butyltin-dichloride (Herwig \& Holwerda, 1986), were not found in $L$. littorea specimen. Yet the quite exceptionally occurring grouping of cristae parallel to the long axis of mitochondria (Fig. 8) may indicate the onset of a stress reaction to toxicants such as TBT. Crespo \& Sala (1986) pointed out that a significant level of organic-tin contamination provokes such an untypical parallel structure of the mitochondria which in turn yields a decoupling of oxidative phosphorylation.

Fig. 14. Gland cell of type A showing membrane-linked secretion vesicle (arrow); scale bar $=4 \mu \mathrm{m}$. GLA: gland cell type A; N: nucleus

Fig. 15. Gland cell of type A1. The structure of this cell-type is more amorphous; scale bar $=4 \mu \mathrm{m}$ GLA1: gland cell type A1; $\mathrm{N}$ : nucleus

Fig. 16. Gland cells of type B are highly prismatic with membrane-unlike secretion; scale bar $=1 \mu \mathrm{m}$. GLB: gland cell type B

Fig. 17. Gland cell of type $C$ shows small grana-like mucus-particles which are not always covered by a membrane; scale bar $=2 \mu \mathrm{m}$. GLC: gland cell type $C_{;} N$ : nucleus 

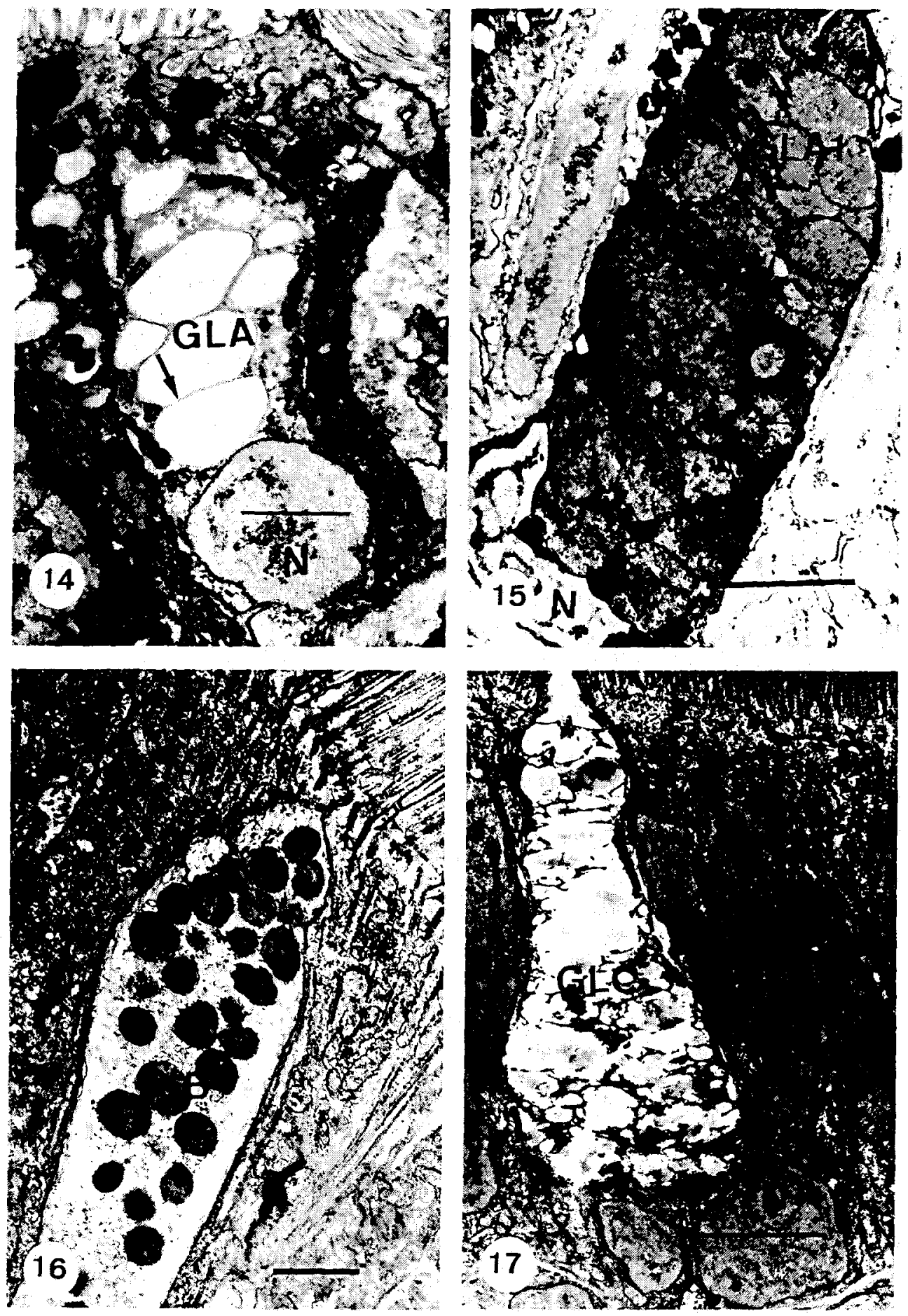
Concerning the number of Iysosomes in the mitochondria region of the penial epithelium which reflects the intensity of detoxification processes (Ord et al., 1988), $L$. littorea differs from male and especially female $O$. aciculata which always display a significantly high number of lysosomes. This fact again points to a modest reaction of the penial epithelium of $L$. littorea to TBT-stress. Similarly, we never observed an increase in the volume of lysosomes in the penial epithelium by destabilization of the membrane which was described by Moore (1985) for the digestive glands of $L$. littorea as a reaction to xenobiotica.

The low pathological impact of TBT on the penial, the sperm groove, and the glandular cushion epithelium in L. littorea is particularly obviously in the nucleus region with its invaginated membranes. An enlargement of the surface of this kind which gives evidence of an active synthesis was not found in the penial and penial duct epithelium of $O$. aciculata. The predominance of euchromatin over heterochromatin in the nuclei of the penial epithelium of this snail is further indicative of low metabolism. One more criterium for an active penial epithelium in $L$. littorea is the unbent and thin basal membrane (Fig.4). Swollen basal membrane reduces the filtration capability and is typical of Cdcontaminated $L$. littorea specimen (Marigomez et al, 1990). An abnormally thickened and invaginated basal membrane was also observed in the penial epithelium of female $O$. aciculata which is normally found only in juvenile tissue.

Only a few specimen of our $L$. littorea display a high rate of vesiculation in the supporting cells of the penial epithelium (Fig. 9), whereas O. aciculata shows similar structures more frequently. These so-called "fluid filled vesicles" serve for detoxification as Ord et al. (1988) demonstrated in animals with Cd-incubation. The different epithelia of the two investigated $L$. littorea populations are also totally devoid of "amoebocytes/ hemocytes" which are seen as indicators of a high level of heavy metal contamination.

In summary, pathological changes in the penial, the sperm groove and the glandular cushion epithelium of $L$. littorea from two habitats known for their significant TBTpollution were not detected in this electron microscopical study. Previous investigations have shown that $L$. littorea accumulates metal ions such as $\mathrm{Cu}$ or $\mathrm{Cd}$ in tissues like the kidney, the digestive gland or the gonad (Martoja, 1980; Mason et al., 1984; Marigomez et al., 1990). The genital system of $L$. littorea obviously has a low sensibility towards TBT; therefore, this animal is not well suited for bio-monitoring this kind of pollution.

Acknowledgements. We want to thank the staff of the Biologische Anstalt Helgoland and of the CNRS station Roscoff for support during field work. We appreciate the thorough review of an earlier draft of this paper by A. Deutsch (Münster) as well as the formal review by E. Stroben (Münster).

Fig. 18. Supporting cells of the penial sperm groove have a border of cilia with pronounced ciliaroots (arrow); scale bar $=1 \mu \mathrm{m}$. BM: basal membrane; CI: cilia; $\mathrm{N}$ : nucleus

Fig. 19. The region of cilia-roots (arrow) of the epithelium of the penial sperm groove shows an abundance of mitochondria; scale bar $=0.5 \mu \mathrm{m}$. CI: cilia; $\mathrm{MI}$ : mitochondria

Fig. 20. Gland cell of type B extends from the tissue to the sperm groove epithelium. Arrow = basal membrane; scale bar $=2 \mu \mathrm{m}$. GLB: gland cell Typ B 

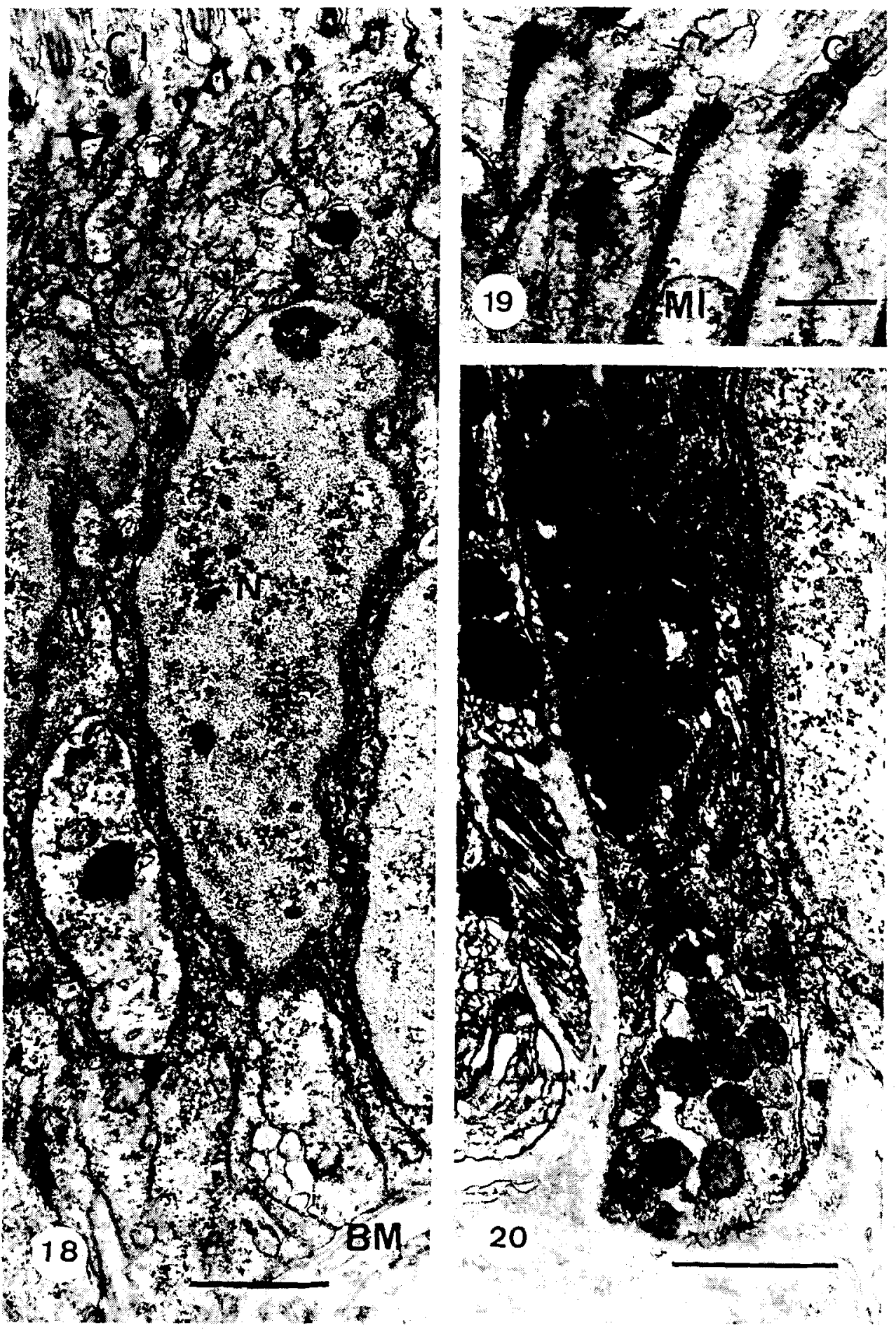


\section{LITERATURE CITED}

Blaber, S.J.M., 1970. The occurrence of a penis-like outgrowth behind the right tentacle in spent females of Nucella lapillus (L.). - Proc. malac. Soc. Lond. 39, 231-233.

Bryan, G.W., Gibbs, P.E. \& Burt, G.R., 1988. A comparison of the effectivness of tri-n-butyltin chloride and five other organotin compounds in promoting the development of imposex in the dog-whelk Nucella lapillus. - J. mar. biol. Ass. U.K. 68, 733-744.

Chagot, D., Alcieu, C., Sanjuan, H. \& Grizel, H., 1990. Sublethal and histopathological effects of trace levels of tributyltin fluoride on adult oysters Crassostrea gigas. - Aquat. Living Resour. 3, 121-130.

Chliamovitch, Y.P. \& Kuhn, C., 1977. Behavioural hematological and histological studies on acute toxicity bis (tri-n-butyltin) oxide in Salmo gairdneri (R.) and Tilapia rendalli (B.). - J. Fish Biol. 10. 575-585.

Crespo, S. \& Sala, R., 1986. Chloride cell mitochondria are target organelles in acute zinc contamination. - Mar. Pollut. Bull. 17, 329-331.

Ferreira, A.M., Cortesao, O.G. \& Vale, C., 1990. Accumulation of metals and organochlorines in tissues of the oyster Crassostrea angulata from the Sado Estuary, Portugal. - Sci. total Environ. $97 / 98,627-639$.

Fioroni, P., Oehlmann, J. \& Stroben, E., 1990. Le pseudohermaphrodisme chez les prosobranches; analyse morphologique et histologique. - Vie Milieu. 40, 45-56.

Fioroni, P., Oehlmann, J. \& Stroben, E., 1991. The pseudohermaphroditism of prosobranchs; morphological aspects. - Zool. Anz. 226, 1-26.

Gibbs, P.E., Bryan, G.W., Pascoe, P.L. \& Burt, G.R., 1990. Reproductive abnormalities in female Ocenebra erinacea (Gastropoda) resulting from tributyltin-induced imposex. - J. mar. biol. Ass. U.K. 70, 639-656.

Hawkins, L.E. \& Hutchinson, S, 1990. Physiological and morphogenetic effects of monophenyltin trichloride on Ocenebra erinacea (L.). - Funct. Ecol, 4, 449-454.

Herwig, L.E. \& Holwerda, D.A., 1986. Cytochemical localisation of tin in freshwater mussels exposed to di-n-butyltin dichloride. - Aquat. Toxicol, 9, 117-128.

Linke, O., 1933. Morphologie und Physiologie des Genitalapparates der Nordseelittorinen. - Wiss. Meeresunters. (Abt. Helgoland) 19 (5), 1-60.

Lowe, D.M. \& Clarke, K.R., 1989. Contaminant-induced changes in the structure of the digestive epithelium of Mytilus edulis. - Aquat. Toxicol. 15, 345-358.

Marigómez, J. A., Cajaraville, M.P., Angulo, E. \& Moya, J., 1990. Ultrastructural alterations in the renal epithelium of cadmium-treated Littorina littorea (L.). - Archs environ. Contam. Toxicol. 19, 863-871.

Martoja, M., 1980. Bioaccumulation du cuivre chez Littorina littorea (L.) (Gastéropode Prosobranche): signification physiologique et écologique. - J. exp. mar. Biol. Ecol. 43, 251-270.

Mason, A. Z., Simkiss, K. \& Ryan, K. P., 1984. The ultrastructural localization of metals in specimens of Littorina littorea collected from clean and polluted sites. - J. mar. biol. Ass. U.K. 64, 699-720.

Matthiessen, P., Waldock, R., Thain, J.E., Milton, S. \& Scrope-Howe, S., 1991. Changes in periwinkle (Littorina littorea) populations following the ban on TBT-based antifoulings on small boats. - C.M./ICES, E5, 15 pp.

Moore, M. N., 1985. Cellular responses to pollutants. - Mar. Pollut. Bull. 16, 134-139.

Ord, M., Bouffler, S. \& Chibber, R., 1988. Cadmium induced change in cell organelles: an ultrastructural study using cadmium sensitivity and resistent muntjac fibroblast cell lines. - Archs Toxicol. $62,133-145$.

Smith, B.S., 1971. Sexuality in the American mud snail, Nassarius obsoletus Say. - Proc. malac. Soc. Lond. 39, 377.

Stroben, E., Brömmel, C., Oehlmann \& J. Fioroni, P., 1993. The genital system of Trivia arctica and Trivia monacha (Prosobranchia, Mesogastropoda) and tributyltin induced imposex. - Zool. Beitr. $34,349-374$. 